\title{
Population demographics and growth rate of Salpa thompsoni on the Kerguelen Plateau
}

\author{
Natasha Henschke ${ }^{\mathrm{a}, *}$, Stéphane Blain ${ }^{\mathrm{b}}$, Yves Cherel ${ }^{\mathrm{c}}$, Cedric Cotte $^{\mathrm{d}}$, Boris Espinasse ${ }^{\mathrm{a}, \mathrm{e}}$, Brian P. \\ V. Hunt ${ }^{\mathrm{a}, \mathrm{e}, \mathrm{f}}$, Evgeny A. Pakhomov ${ }^{\mathrm{a}, \mathrm{e}, \mathrm{f}}$ \\ ${ }^{a}$ Department of Earth, Ocean and Atmospheric Sciences, University of British Columbia, Vancouver, British Columbia, Canada \\ ${ }^{\mathrm{b}}$ Sorbonne Universités, CNRS, Laboratoire d'Océanographie MICrobienne, F-66650 Banyuls sur Mer, France \\ ${ }^{\mathrm{c}}$ Centre d'Etudes Biologiques de Chizé (CEBC), UMR 7372 CNRS-La Rochelle Université, 79360 Villiers-en-Bois, France \\ ${ }^{\mathrm{d}}$ LOCEAN, Sorbonne Universités (UPMC, Univ Paris 06) CNRS-IRD-MNHN, Paris, France \\ ${ }^{\mathrm{e}}$ Institute for the Oceans and Fisheries, University of British Columbia, Vancouver, British Columbia, Canada \\ ${ }^{\mathrm{f}}$ Hakai Institute, PO Box 309, Heriot bay, BC, Canada
}

\section{A B S T R A C T}

This study aimed to obtain the first estimates of $S$. thompsoni population dynamics and growth rates over the Kerguelen Plateau (Southern Indian Ocean). Micronekton, including salps, were repeatedly sampled during late summer to early autumn (26th February - 15th March 2018) at contrasting hydrological stations on the Kerguelen Plateau in the southern proximity of Kerguelen Islands. At two stations, $S$. thompsoni made up almost half of the micronekton biomass. Environmental conditions were important in determining the density and development of $S$. thompsoni populations. Growth rates $\left(0.5-7.0 \% \mathrm{~d}^{-1}\right)$ were higher than previously reported from the Antarctic Peninsula $\left(0.3-4.6 \% \mathrm{~d}^{-1}\right.$ ) but lower than near the Antarctic Polar Front (APF; $3.7-20.7 \% \mathrm{~d}^{-1}$ ). Despite warm surface waters $\left(4-5{ }^{\circ} \mathrm{C}\right.$ ), low chlorophyll $a$ concentrations restricted the salp populations from growing as fast as populations near the APF. Because the Kerguelen Plateau region deflects a branch of warm water southward towards Antarctica, more studies of $S$. thompsoni population dynamics across multiple seasons are needed to fully understand their importance over the Kerguelen Plateau and their invasion potential into higher latitudes.

\section{Introduction}

The salp, Salpa thompsoni, is a prominent non-selective grazer in the Southern Ocean (Voronina, 1998) with a wide distribution $\left(40-65^{\circ} \mathrm{S}\right.$; Foxton, 1966) that often occurs in dense swarms in the warmer waters of the Antarctic Polar Frontal (APF) zone (Foxton, 1966; Pakhomov et al., 2002; Loeb and Santora, 2012; Henschke and Pakhomov, 2018). Unlike crustacean zooplankton that are key species in food webs of the Southern Ocean (Everson, 2000; Bocher et al., 2001), S. thompsoni have few known predators (Pakhomov et al., 2002; Henschke et al., 2016). However, salps have high filtration rates, allowing them to have a grazing impact that can exceed the total daily primary production when they are abundant (Dubischar and Bathmann, 1997). Additionally, as they can feed on a range of particles spanning in size over three orders of magnitude (Henschke et al., 2016), they are potentially important competitors to other phytoplankton grazers. The prominence of salps in the Southern Ocean food-webs and biogeochemical processes is recognized and reflected in recent modelling studies (Hoover et al., 2012; Suprenand and Ainsworth, 2017) and their inclusion into biogeochemical models is critical to parameterize the Southern Ocean carbon and iron cycles (Pakhomov et al., 2002; Henschke et al., 2016; Maldonado et al., 2016). Currently key limitations to the further advancement of biogeochemical models is the paucity of data on physiological parameters, feeding preferences and biomass observations of the Southern Ocean pelagic tunicates (Le Quéré et al., 2016).

Swarms of $S$. thompsoni populations form because of synchronized reproductive efforts, usually after the summer bloom of phytoplankton, with highest abundances occurring from summer to autumn (Foxton, 1966; Atkinson et al., 2017). There are relatively few studies on S. thompsoni in the Indian sector of the Southern Ocean $\left(20^{\circ} \mathrm{E}-170^{\circ} \mathrm{E}\right)$ compared to the Pacific and Atlantic sectors, especially during autumn (March-May) (Kelly et al., 2020). This lack of sampling is evident in KRILLBASE, the most comprehensive database of $S$. thompsoni abundance that spans 90 years. Only $19 \%$ of $S$. thompsoni observations in KRILLBASE are from the Indian sector, and $2 \%$ during March (Atkinson et al., 2017). Instead, the majority of salp sampling has occurred in the Atlantic sector $\left(70^{\circ} \mathrm{W}-20^{\circ} \mathrm{E} ; 75 \%\right)$, during the Austral summer (December - February, 73\%) (Atkinson et al., 2017).

The Kerguelen Plateau, south-east of the Kerguelen Islands, is a major barrier to the eastward flowing Antarctic Circumpolar Current

\footnotetext{
* Corresponding author.

E-mail address: nhenschke@eoas.ubc.ca (N. Henschke).
} 
(ACC) in the Indian sector of the Southern Ocean (Pakhomov, 2000; Park et al., 2008). Interactions with the bottom topography supply iron to surface waters and the Kerguelen Plateau is associated with elevated chlorophyll concentrations with a dynamic and prolonged phytoplankton bloom starting in late October, peaking between early November and late December and ending by late February (Blain et al., 2001; Schlitzer, 2002; Blain et al., 2007). This is in contrast to the majority of the Southern Ocean, where phytoplankton productivity is limited, resulting in high-nitrate low-chlorophyll (HNLC) areas (Blain et al., 2001). There are several studies of mesozooplankton and micronekton from the area around Kerguelen Islands (e.g. Duhamel et al., 2000; Carlotti et al., 2008; Béhagle et al., 2017) and one including the salp, S. thompsoni (Hunt et al., 2011). However, to date there is only one study that explored the population structure of the $S$. thompsoni population south of the Kerguelen Plateau (Kelly et al., 2020). This is despite the Kerguelen Plateau region being a suitable habitat (chlorophyll rich with surface waters warmer than $3{ }^{\circ} \mathrm{C}$ ) (Henschke and Pakhomov, 2018) for the development of large $S$. thompsoni swarms.

In late summer to early autumn of 2018, the "Marine Ecosystem Biodiversity and Dynamics of Carbon around Kerguelen: an integrated view" (MOBYDICK) expedition sampled the micronekton community, including salps, at stations over the southern Kerguelen Plateau with contrasting hydrological/biological (in terms of primary production) conditions. In this study, we explore the population size and structure of $S$. thompsoni at contrasting stations at the end of a long phytoplankton bloom.

\section{Methods}

\subsection{Oceanographic sampling}

Micronekton sampling was undertaken on the RV Marion Dufresne II in the region south (off Kerguelen Plateau) and south-east of Kerguelen Islands (over the Kerguelen Plateau) during the MOBYDICK expedition from the 26th February to 19th March 2018. This voyage was a continuation of three previous programs in the area: the Kerguelen
Ocean and Plateau compared Study (KEOPS) in summer 2005, KEOPS2 in spring 2011 (Trull et al., 2015) and the Myctophid assessment in relation to Oceanographic conditions: a three Dimension Density Distribution approach combining Modelling, Acoustic-and Predators' data (MyctO-3D-MAP) in summer 2014. The MOBYDICK station positions were selected to coincide with areas sampled during the three previous surveys. In total, four stations were sampled: one station M2 on the plateau, two off-plateau stations (M3, M4) to the west of Kerguelen Islands, and one off-plateau station M1 located to the east of Kerguelen Islands, with repeated sampling occurring at stations M2, M3 and M4 (Fig. 1; Table 1).

At each station, a SeaBird SBE 19+ Conductivity-Temperature-Depth (CTD) probe equipped with a calibrated Chelsea Aqua-Tracker Mk3 fluorometer mounted to a rosette frame holding $12 \mathrm{~L}$ Niskin bottles was used to profile temperature, salinity and fluorescence prior to the micronekton sampling. Water collected in the Niskin bottles was used for chlorophyll $a$ extraction and HPLC analysis as per Uitz et al. (2008). Fluorometer readings were converted to chlorophyll $a$ concentrations by calculating a linear fit between CTD fluorometer readings and corresponding Niskin bottle samples $\left(n=40, \mathrm{R}^{2}=0.93\right)$. Mean $( \pm \mathrm{SD})$ hydrographic properties were calculated for the mixed layer at each station. The mixed layer depth was determined from the minimum depth to which $\mathrm{T}<\mathrm{T}(10 \mathrm{~m})-0.4{ }^{\circ} \mathrm{C}$ (Condie and Dunn, 2006).

During a sampling event at each station, three daytime and three nighttime trawls were conducted using the Mesopelagos trawl designed by IFREMER (Institut Français de Recherche pour l'exploitation de la Mer), Laboratory of Fisheries Biology and Technology, Lorient, France (Meillat, 2012). This non-closing trawl has a mean mouth opening of 35 $\mathrm{m}^{2}$ and a total length of $58 \mathrm{~m}$ (Olivar et al., 2017). The trawl has a mesh size of $30 \mathrm{~mm}$ in the wings, reducing to $4 \mathrm{~mm}$ in the codend and is designed to target organisms ranging in size from approximately 1-30 $\mathrm{cm}$ long. A Scanmar acoustic device (Åsgårdstrand, Norway) was attached to the net for real time monitoring of trawl depth simultaneously with acoustic measurements (Williams and Koslow, 1997). Sampling depths were selected using the acoustic backscatter information and trawls targeted high backscattering signals in surface, middle
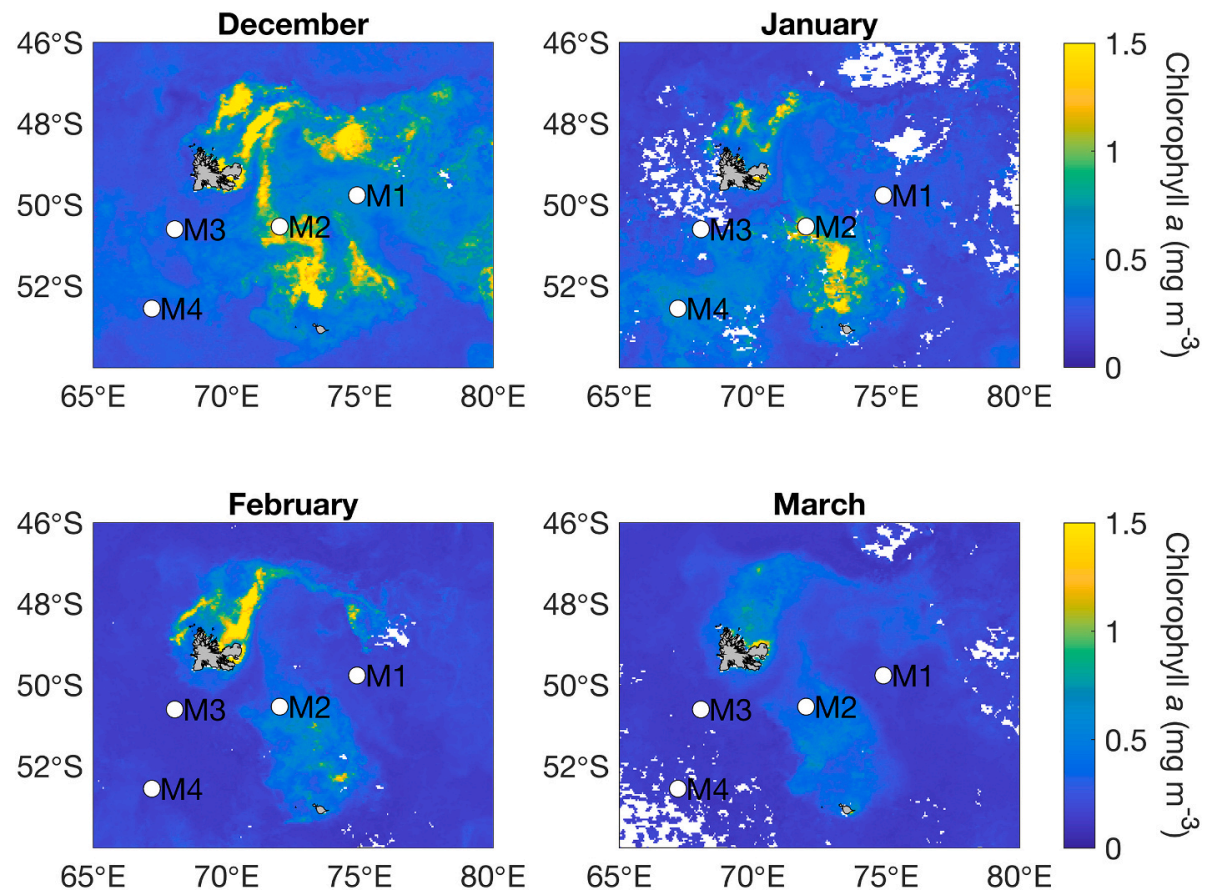

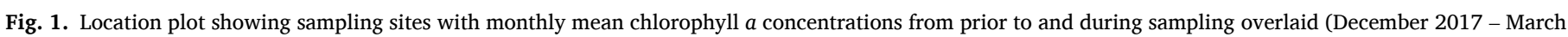

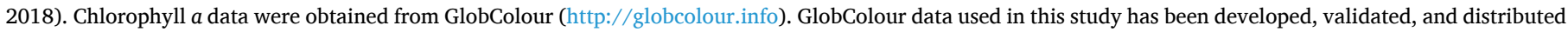
by ACRI-ST, France. Areas with no data (cloud cover) are indicated in white. 
Table 1

Sampling location, dates and maximum depths for trawls.

\begin{tabular}{|c|c|c|c|c|c|c|c|c|c|c|c|c|c|}
\hline Site & $\begin{array}{l}\text { Location } \\
\left({ }^{\circ} \mathrm{S},{ }^{\circ} \mathrm{E}\right)\end{array}$ & Visit & $\begin{array}{l}\text { Sampling date } \\
\text { (DD/MM/YY) }\end{array}$ & $\begin{array}{l}\text { Day/ } \\
\text { Night }\end{array}$ & $\begin{array}{l}\text { Sampling } \\
\text { depth (m) }\end{array}$ & Visit & $\begin{array}{l}\text { Sampling date } \\
\text { (DD/MM/YY) }\end{array}$ & $\begin{array}{l}\text { Day/ } \\
\text { Night }\end{array}$ & $\begin{array}{l}\text { Sampling } \\
\text { depth (m) }\end{array}$ & Visit & $\begin{array}{l}\text { Sampling date } \\
(\mathrm{DD} / \mathrm{MM} / \mathrm{YY})\end{array}$ & $\begin{array}{l}\text { Day/ } \\
\text { Night }\end{array}$ & $\begin{array}{l}\text { Sampling } \\
\text { depth (m) }\end{array}$ \\
\hline \multirow[t]{6}{*}{ M1 } & 49.85, & 1 & $09 / 03 / 18$ & $\mathrm{D}$ & 400 & & & & & & & & \\
\hline & 74.90 & & & $\mathrm{D}$ & 50 & & & & & & & & \\
\hline & & & & $\mathrm{D}$ & 632 & & & & & & & & \\
\hline & & & & $\mathrm{N}$ & 51 & & & & & & & & \\
\hline & & & & $\mathrm{N}$ & 290 & & & & & & & & \\
\hline & & & & $\mathrm{N}$ & 617 & & & & & & & & \\
\hline \multirow[t]{6}{*}{ M2 } & 50.62 & 1 & $26 / 02 / 18-$ & $\mathrm{D}$ & NS & 2 & $07 / 03 / 18$ & $\mathrm{D}$ & 170 & 3 & $16 / 03 / 18$ - & $\mathrm{D}$ & 105 \\
\hline & 72.00 & & $27 / 02 / 18$ & $\mathrm{D}$ & 210 & & & $\mathrm{D}$ & 70 & & $17 / 03 / 18$ & $\mathrm{D}$ & 340 \\
\hline & & & & $\mathrm{D}$ & 350 & & & $\mathrm{D}$ & 350 & & & $\mathrm{D}$ & 190 \\
\hline & & & & $\mathrm{N}$ & 346 & & & $\mathrm{~N}$ & 317 & & & $\mathrm{~N}$ & 65 \\
\hline & & & & $\mathrm{N}$ & 55 & & & $\mathrm{~N}$ & 50 & & & $\mathrm{~N}$ & 377 \\
\hline & & & & $\mathrm{N}$ & 158 & & & $\mathrm{~N}$ & 175 & & & $\mathrm{~N}$ & 30 \\
\hline \multirow[t]{6}{*}{ M3 } & 50.68 & 1 & $04 / 03 / 18^{\mathrm{a}}$ & $\mathrm{D}$ & $55^{\mathrm{a}}$ & 2 & $18 / 03 / 18$ - & $\mathrm{D}$ & 814 & & & & \\
\hline & 68.06 & & $15 / 03 / 18$ & $\mathrm{D}$ & $460^{\mathrm{a}}$ & & $19 / 03 / 18$ & $\mathrm{D}$ & 600 & & & & \\
\hline & & & & $\mathrm{D}$ & 683 & & & $\mathrm{D}$ & 65 & & & & \\
\hline & & & & $\mathrm{N}$ & 610 & & & $\mathrm{~N}$ & 802 & & & & \\
\hline & & & & $\mathrm{N}$ & 90 & & & $\mathrm{~N}$ & 650 & & & & \\
\hline & & & & $\mathrm{N}$ & 415 & & & $\mathrm{~N}$ & 73 & & & & \\
\hline \multirow[t]{6}{*}{ M4 } & 52.60 & 1 & $01 / 03 / 18-$ & $\mathrm{D}$ & 93 & 2 & $14 / 03 / 18$ & $\mathrm{D}$ & 85 & & & & \\
\hline & 67.20 & & $02 / 03 / 18$ & $\mathrm{D}$ & 575 & & & $\mathrm{D}$ & 610 & & & & \\
\hline & & & & $\mathrm{D}$ & 425 & & & $\mathrm{D}$ & 410 & & & & \\
\hline & & & & $\mathrm{N}$ & 400 & & & $\mathrm{~N}$ & 600 & & & & \\
\hline & & & & $\mathrm{N}$ & 96 & & & $\mathrm{~N}$ & 80 & & & & \\
\hline & & & & $\mathrm{N}$ & 575 & & & $\mathrm{~N}$ & 400 & & & & \\
\hline
\end{tabular}

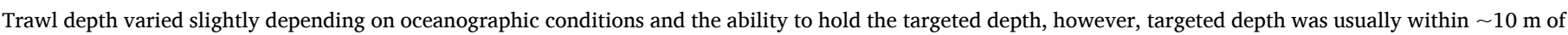
the maximum depth. NS - no sample.

a M3 visit 1 had to be performed over two separate visits due to bad weather. The first two-day sampling events occurred on 04/03/18, whereas the remaining day and night events occurred on 15/03/18. Only data from 15/03/18 were considered for salp length analyses.

and deep layers (Table 1). Trawls were targeting the micronketon population, hence, the depth of each tow varied depending on station depth or the backscatter information, but were generally between 50 and $100 \mathrm{~m}, 200-650 \mathrm{~m}$ and $300-800 \mathrm{~m}$ for each layer. For the successive trawl strategy, the daytime succession was random, whereas the deepest trawls were performed first during the night to ensure that all migrators had time to move to the surface layers by the time of surface sampling. During the trawl deployment and retrieval, vessel speed was lowered to $<1 \mathrm{~m} \mathrm{~s}^{-1}$, preventing the full trawl opening that largely reduced its sampling efficiency. After reaching target depth, the vessel maintained an average speed of $1 \mathrm{~m} \mathrm{~s}^{-1}$ for $\sim 30 \mathrm{~min}$ to ensure that organisms were mainly caught at the targeted depth. Filtered volume was estimated only during the tow at the target depth, considering a cylinder with the surface of the trawl opening and the distance traveled during the haul. Nevertheless, the contamination that may have occurred during the deployment/retrieval of the trawl was qualitatively estimated by comparing the samples at the different layers of the same visit of stations, which appeared to be insignificant. Immediately after sampling, $S$. thompsoni individuals were separated from other micronekton in the trawl and weighed. If salp catch was high, a subsample containing a minimum of $\geq 100$ individuals was randomly selected, analyzed and subsequently extrapolated to the total catch. Individuals were sexed, measured for the oral-atrial body length (OAL) and their maturity stage identified (Foxton, 1966). S. thompsoni maturity stages were classified by degrees of reproductive development (for more details see Pakhomov and Hunt, 2017). In short, oozoids are reproductively immature from release (stage 0 ) until the development (stages $4 \mathrm{~A}$ and $4 \mathrm{~B}$ ) and release (stage 5A and 5B) of blastozooid buds. Blastozooids are born female and are reproductively immature from release (stage 0 ) until the development and release of an oozoid embryo (stage 4). Once blastozooids have released the oozoid embryo, they develop testis and function as males (stage M). Females that do not have a viable embryo, from either lack of fertilization or incorrect development, were classified as stage X.

Due to the large mesh size at the beginning of the trawl, our samples may consistently underestimate individuals smaller than $40 \mathrm{~mm}$ in length. A $S$. thompsoni individual that is $40 \mathrm{~mm}$ in total length, would approximately equate to an individual with OAL of $20-25 \mathrm{~mm}$. While individuals smaller than $25 \mathrm{~mm}$ OAL comprise approximately $50 \%$ of our samples, blastozooids would have been sampled in aggregated chains increasing their sampling efficiency. Small oozoids may have been undersampled, however in general they made up a very small proportion of the sampled population (3\%). The mesh size is a shortcoming of this trawl, particularly for sampling $S$. thompsoni, and while the potential undersampling of small individuals is likely to have occurred, it was consistent across all stations.

\subsection{Satellite data and Lagrangian diagnostics}

In order to investigate the inter-visit environmental variability at each station, the water mass history was characterized by estimating the transport of water parcels across the study region. Geostrophic currents used in the Lagrangian analysis were derived from the multi-satellite global altimetry product SSALTO/DUACS, with a temporal and spatial resolution of 1 day and $1 / 4^{\circ}$, respectively. Trajectories were derived by applying a Runge-Kutta fourth order scheme with a time step of $6 \mathrm{~h}$. Velocity fields were linearly interpolated in both space and time. The aim was to compare the water dispersion pathways computed downstream (backward-in-time) and upstream (forward-in-time) of the stations. We used an altimetry-based Lagrangian calculation from/to the starting period of the cruise, and computed the age of water parcels advected from/to each station defined here as a disk of $40 \mathrm{~km}$ radius. This approach has been validated for the island mass effect, to reproduce the Kerguelen bloom (d'Ovidio et al., 2015) and its onward transport (Cotté et al., 2015).

\subsection{Statistical analyses}

Cohort analysis of $S$. thompsoni blastozooids and oozoids were determined using Gaussian mixture models (GMM) in $\mathrm{R}$ (package: mixtools, function: normmixEM) based on size-frequency histograms. Blastozooids were binned into $1 \mathrm{~mm}$ size intervals, whereas oozoids were binned into $5 \mathrm{~mm}$ size intervals to better visualize the major 
cohorts. This method used the expectation-maximization algorithm to compute the best fit to the observed data assuming the Gaussian distribution. Depending on the number of distinct modal peaks in the sizefrequency histograms, the model identified a range of Gaussian components. Once each component was identified, the means attributed to each cohort were linked through each sampling visit to capture the growth trajectory for each different cohort. The growth trajectory over time (i.e., the change in mean size for linked cohorts) was used to calculate population growth rates. A caveat of this approach is that it assumes that the same population was sampled on each visit. However, the Lagrangian diagnostics (see 3.1) indicated that it was likely the case and we sampled the same water mass inhabited the same salp population. One-way analyses of variance (ANOVA) were used to compare oceanographic conditions and micronekton abundance between stations.

\section{Results}

\subsection{Regional oceanography}

Two to three months (December - January) prior to sampling, a large chlorophyll $a$ bloom occurred at stations M1 and M2, with the latter being comparatively more productive than the former one (Fig. 1). At the time of sampling (March), chlorophyll $a$ concentrations at M1 and M2 had declined remaining higher than at M3 and M4 $\left(F_{3,30}=20.38, p\right.$ $<0.001$; Table 2; Fig. 2). Waters in the mixed layer at M3 were significantly warmer $\left(F_{3,30}=15.02, p<0.001\right)$, and less saline $\left(F_{3,30}=93.57\right.$, $p<0.001$; Table 2). An absence of a temperature minimum at $200 \mathrm{~m}$ at M3 confirmed that it was conducted north of the APF, whereas M1, M2 and M4 stations were located south of the APF in the Antarctic Zone (AAZ; Fig. 2). There was minimal horizontal transport at stations M2, M3 and M4, where the water parcels recirculated (Fig. 3 for the backward-tracking and supplementary material for the forward tracking). Station M1 appeared to be more dynamic. This is illustrated by a residence time up to about 60 days, before the water masses moved mainly eastward (Fig. 3). This suggests that the same water masses were sampled during each visit of the repeatedly sampled stations M2, M3 and M4.

\subsection{Salpa thompsoni density and distribution}

Total salp abundance during the day was similar across stations, but was significantly higher at M1 during the night than at M3 and M4 ( $F_{7,46}$ $=2.71, p=0.02$; Table 3). Salp abundances ranged from $<1$ to 747 individuals (ind.) $1000 \mathrm{~m}^{-3}\left(<1\right.$ to $651 \mathrm{mg} \mathrm{WW} \mathrm{m}^{-3}$ ) with the mean $( \pm$ SD) abundance across all stations reaching $27 \pm 111$ ind. $1000 \mathrm{~m}^{3}$ (Table 3). Between visits at M2, M3 and M4, S. thompsoni densities (both abundance and biomass) did not vary significantly (Table 3). $S$. thompsoni made up a larger proportion of total micronekton biomass at M1 $(42 \pm 18 \%)$ and M2 $(42 \pm 30 \%)$ than M3 $(5 \pm 4 \%)$ and M4 (3 \pm $\left.2 \% ; F_{3,46}=8.68, p<0.001\right)$, however, the biomass of other micronekton

Table 2

Mean $( \pm S D$ ) hydrographic properties in each sampling location for the mixed layer.

\begin{tabular}{lllll}
\hline Station & $\begin{array}{l}\text { Mixed layer } \\
\text { depth }(\mathrm{m})\end{array}$ & $\begin{array}{l}\text { Temperature } \\
\left({ }^{\circ} \mathrm{C}\right)\end{array}$ & Salinity & $\begin{array}{l}\text { Chlorophyll } a(\mathrm{mg} \\
\left.\mathrm{C} \mathrm{m}^{-3}\right)\end{array}$ \\
\hline M1 & 60 & $4.82 \pm 0.55^{\mathrm{ab}}$ & $\begin{array}{l}33.89 \pm \\
0.01^{\mathrm{a}}\end{array}$ & $0.37 \pm 0.03^{\mathrm{a}}$ \\
& & $5.11 \pm 0.21^{\mathrm{bc}}$ & $\begin{array}{l}33.86 \pm \\
0.01^{\mathrm{b}}\end{array}$ & $0.31 \pm 0.06^{\mathrm{ac}}$ \\
M2 & 80 & $5.37 \pm 0.18^{\mathrm{c}}$ & $\begin{array}{l}33.82 \pm \\
0.01^{\mathrm{c}}\end{array}$ & $0.20 \pm 0.02^{\mathrm{b}}$ \\
M3 & 80 & & \\
& & $4.40 \pm 0.27^{\mathrm{a}}$ & $\begin{array}{l}33.85 \pm \\
0.02^{\mathrm{b}}\end{array}$ & $0.26 \pm 0.04^{\mathrm{c}}$ \\
& & & \\
\hline
\end{tabular}

Letters $(\mathrm{a}-\mathrm{c})$ denote significant differences at $\mathrm{p}<0.05$. did not differ significantly across stations (overall mean: $22 \pm 34 \mathrm{mg}$ $\mathrm{WW} \mathrm{m}^{-3}$; Fig. 4). Blastozooids and oozoids were distributed throughout the water column, but were sampled at significantly deeper depths during the daytime $\left(F_{1,14}=19.31, p<0.001\right)$, suggesting diel vertical migration (Fig. 5). Daytime weighted mean depth (WMD) for blastozooids and oozoids were $518( \pm 154)$ and $486( \pm 151)$ m respectively. Correspondingly, nighttime WMD for blastozooids and oozoids were $200( \pm 147)$ and $213( \pm 124) \mathrm{m}$ respectively.

\subsection{Size and stage distribution}

Blastozooids and oozoids at M1 had a multimodal size distribution dominated by smaller ( $<25 \mathrm{~mm}$ ) individuals (Fig. $6 a, b$ ). Blastozooids were dominated by young individuals (stages $0-2 ; 69 \%$ ), with stage $\mathrm{X}$ individuals accounting for $24 \%$ of total numbers (Fig. 7 a). Oozoids were dominated by reproductively immature individuals still developing buds (stages 2 - 4B; 77\%; Fig. 7b).

At M2, blastozooids had a multimodal size distribution across each visit and individuals were larger compared to the other stations, with blastozooids and oozoids reaching 76 and $130 \mathrm{~mm}$ in length, respectively (Fig. 6). Blastozooids during the first visit (smallest cohort: 24 $\mathrm{mm}$ ) were substantially larger compared to the second (14 $\mathrm{mm}$ ) and third visits $(13 \mathrm{~mm})$ (Fig. $6 c, e, g)$. Males dominated the blastozooid population at M2 during the first visit (62\%) before recently released individuals (stage 0 ) became more prominent during the second visit (29\%) and third visit (28\%; Fig. $7 c, d$ ). By the third visit, males were significantly smaller $\left(36 \mathrm{~mm}, \mathrm{~F}_{1,70}=15.88, \mathrm{p}<0.001\right)$ than at the previous visit $(40 \mathrm{~mm})$. Oozoids had a multimodal distribution of small/ medium $(40-50 \mathrm{~mm})$ and large $(>75 \mathrm{~mm}$ ) individuals (Fig. 6d,f,h). Oozoids were dominated by individuals that were developing buds (stages 3 and 4A), and this increased across each visit (from 43 to 58\%; Fig. $7 d$ ). Correspondingly, the proportion of reproductive individuals (stages $4 \mathrm{~B}$ to $5 \mathrm{~B}$ ) increased from the first visit (31\%) to the second (42\%) and third (34\%) visits.

Blastozooids at M3 had a size distribution dominated by smaller, young blastozooids across both the first ( $47 \%$ were stage 2 ) and the second visits (51\% were stages 1 and 2; Figs. 5i,k; 7e). Additionally, there were high proportions of stage $\mathrm{X}$ individuals across both visits ( $20 \%$ and $32 \%$ respectively) and an absence of reproducing individuals (stage 4) as well as males. Size distributions of oozoids at M3 were similar across both visits with four cohorts ranging from $\sim 20 \mathrm{~mm}$ to $\sim 70 \mathrm{~mm}$ (Fig. 6j,l). Oozoids were dominated by reproductively immature individuals (stage 3 ) and specimens beginning to produce buds (stages 4A and 4B) across both visits (83\% and $82 \%$ respectively, Fig. $7 f$ ). The similarities at M3 across both visits were likely due to sampling occurring 3 days apart whereas M2 and M4 visits were separated by $9-12$ days (Table 1 ).

At M4, blastozooids were dominated by smaller, recently released individuals (stage $0 ; 52 \%$ ) during the first visit, and slightly more developed young individuals (stages 0 and $1 ; 60 \%$ ) during the second visit (Fig. $6 m, o ; g$ ). There were two cohorts of oozoids at M4 across both sampling events comprised of small/medium individuals $(30-60 \mathrm{~mm}$ ) (Fig. $6 n, p$ ). Oozoids were dominated by young, reproductively immature individuals during the first (stages 2 and 3; 72\%) and second visits (stages 3 and 4A; 82\%; Fig. 7h). Reproductive oozoids (stage 4 onwards) at M3 and M4 were significantly smaller than at M1 and M2 $\left(F_{3,439}=\right.$ 14.3, $p<0.01$ ).

\subsection{Growth rates}

Cohort analysis of $S$. thompsoni blastozooid and oozoid populations identified 2-4 distinct cohorts at each station (Fig. 6). The means of each cohort were linked to determine the growth trajectories for each cohort based on sampling dates. Salpa thompsoni growth rates were similar across stations and did not differ significantly (Fig. 8). Growth rates ranged from 1.57 to $6.02 \% \mathrm{~d}^{-1}\left(0.38-1.18 \mathrm{~mm} \mathrm{~d}^{-1}\right)$ for blastozooids and 

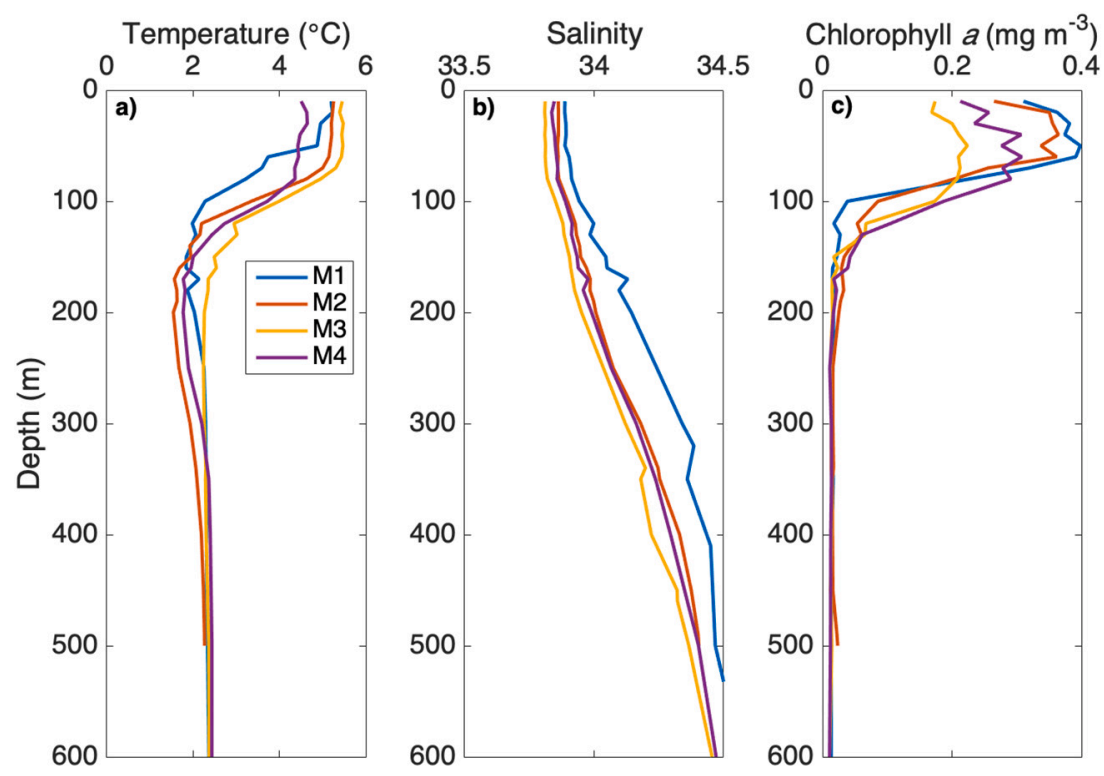

Fig. 2. Depth profiles of mean a) temperature, b) salinity and c) chlorophyll $a$ at each sampling station.
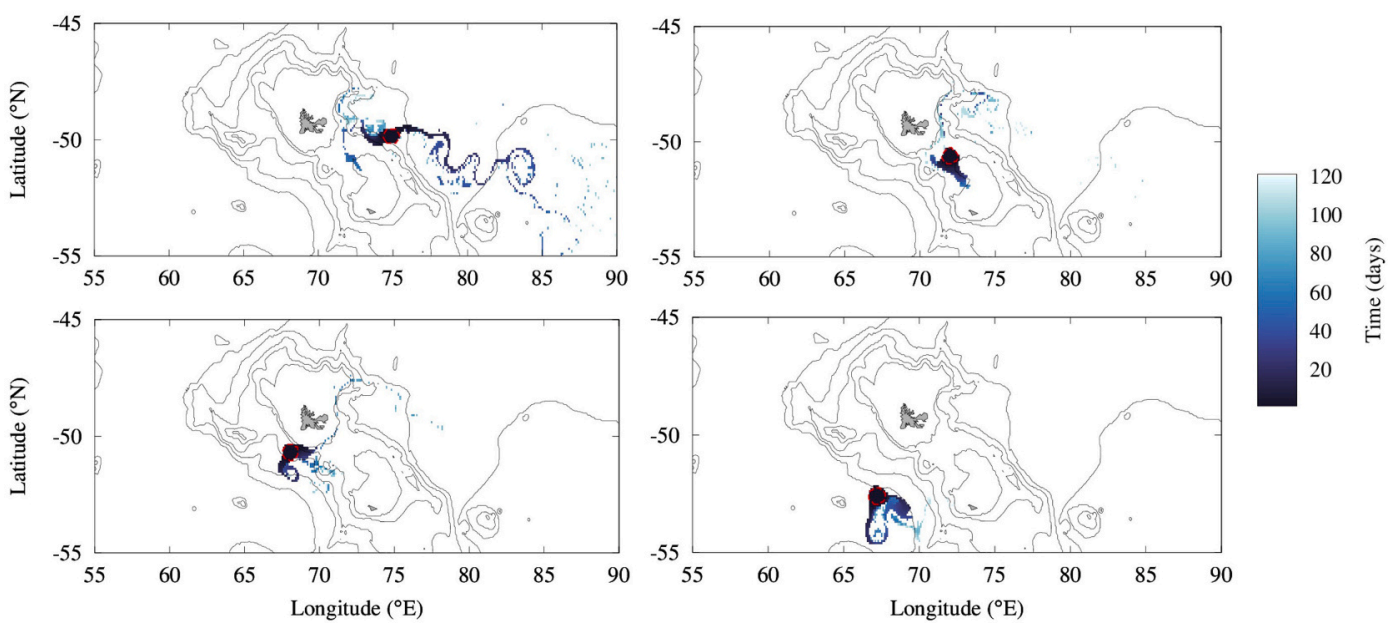

Fig. 3. Backward-tracking results from Lagrangian analysis showing residence time of water parcels at each sampling location (M1 (top left), M2 (top right), M3 (bottom left) and M4 (bottom right)). Red circles indicate $40 \mathrm{~km}$ radius of sampling area. (For interpretation of the references to colour in this figure legend, the reader is referred to the web version of this article.)

from 0.45 to $7.01 \% \mathrm{~d}^{-1}\left(0.34-3.25 \mathrm{~mm} \mathrm{~d}^{-1}\right)$ for oozoids and declined with increasing size (Fig. 8).

\section{Discussion}

The Kerguelen Plateau region is considered to be an optimal environment for the successful development of $S$. thompsoni populations, because it is influenced by warm waters of the Polar Frontal Zone (Park et al., 2008) and is characterized by the largest seasonal phytoplankton blooms of any Southern Ocean island systems (Blain et al., 2007). Indeed, $S$. thompsoni is regularly found off the Kerguelen shelf (Pakhomov, 1995; Hunt et al., 2011) and as far south of the Kerguelen Plateau as $65^{\circ} \mathrm{S}$ in the proximity of the Banzare Bank and of the northeastern Prydz Bay Region (Pakhomov, 1989, 1993a; Hosie, 1994; Pakhomov, 2000; Trebilco et al., 2019; Kelly et al., 2020).

A large phytoplankton bloom was observed in December and January at two (M1 and M2) out of four sampled stations, which largely subsided by late February - early March when actual sampling occurred. Minimal water transport at stations M2 - M4 during the time of sampling suggests that the same micronekton and salp populations were sampled during repeated visits. Previous studies documented extreme patchiness in the $S$. thompsoni distribution, when densities in the consecutive 1 to 5 $\mathrm{km}$ samples varied up to two orders of magnitude (Foxton, 1966). Therefore, while the same salp population was potentially sampled, variability in actual densities between visits and/or samplings could be high.

Salpa thompsoni abundance in our study was within the low to middle range of values $\left(<1-6500\right.$ ind. $1000 \mathrm{~m}^{-3}$ ) observed during summer and autumn at the APF region (Henschke and Pakhomov, 2018). The only previous estimates of $S$. thompsoni abundance in the vicinity of the Kerguelen Plateau are available from 1987 to 1988 (Pakhomov, 1993b; Hunt et al., 2011). During February and April 1987, salp densities of $>100$ ind. $1000 \mathrm{~m}^{-3}$ were found southeast of the Kerguelen Islands (near station M2) in the region affected by an influx of warmer sub-Antarctic waters (Pakhomov, 1993b; Hunt et al., 2011). During the following summer (February 1988), the APF passed to the north of the Kerguelen Islands leading to lower $S$. thompsoni abundances to the south-east of Kerguelen Islands and their northward displacement (Pakhomov, 1995; 
Table 3

Mean ( \pm SD) $S$. thompsoni abundance on the Kerguelen Plateau pooled across depth. Samples are separated by day/night and blastozooid/oozoid.

\begin{tabular}{|c|c|c|c|c|c|}
\hline \multirow[t]{2}{*}{ Station } & \multicolumn{2}{|l|}{ Day } & \multicolumn{2}{|l|}{ Night } & \multirow{2}{*}{$\begin{array}{l}\text { Total } \\
\text { (ind. } \\
1000 \\
\mathrm{~m}^{-3} \text { ) }\end{array}$} \\
\hline & $\begin{array}{l}\text { Blastozooid } \\
\text { (ind. } 1000 \\
\mathrm{~m}^{-3} \text { ) }\end{array}$ & $\begin{array}{l}\text { Oozoid } \\
\text { (ind. } \\
1000 \\
\mathrm{~m}^{-3} \text { ) }\end{array}$ & $\begin{array}{l}\text { Blastozooid } \\
\text { (ind. } 1000 \\
\mathrm{~m}^{-3} \text { ) }\end{array}$ & $\begin{array}{l}\text { Oozoid } \\
\text { (ind. } \\
1000 \\
\mathrm{~m}^{-3} \text { ) }\end{array}$ & \\
\hline M1 & $2.50 \pm 2.18$ & $\begin{array}{l}5.67 \pm \\
4.94\end{array}$ & $\begin{array}{l}156.89 \pm \\
262.66\end{array}$ & $\begin{array}{l}107.16 \pm \\
156.02\end{array}$ & $\begin{array}{l}136.12 \\
\pm 299.63\end{array}$ \\
\hline M2_1 & $2.59 \pm 3.66$ & $\begin{array}{l}1.75 \pm \\
2.48\end{array}$ & $\begin{array}{l}17.96 \pm \\
21.72\end{array}$ & $\begin{array}{l}9.18 \pm \\
10.87\end{array}$ & $\begin{array}{l}18.02 \pm \\
20.12\end{array}$ \\
\hline M2_2 & $0.02 \pm 0.04$ & $\begin{array}{l}0.34 \pm \\
0.29\end{array}$ & $\begin{array}{l}70.73 \pm \\
56.84\end{array}$ & $\begin{array}{l}25.14 \pm \\
18.09\end{array}$ & $\begin{array}{l}48.12 \pm \\
59.37\end{array}$ \\
\hline M2_3 & $0.05 \pm 0.09$ & $\begin{array}{l}0.66 \pm \\
1.15\end{array}$ & $3.40 \pm 2.68$ & $\begin{array}{l}7.68 \pm \\
6.39\end{array}$ & $\begin{array}{l}5.90 \pm \\
8.00\end{array}$ \\
\hline M3_1 & $0.05 \pm 0.07$ & $\begin{array}{l}0.10 \pm \\
0.10\end{array}$ & $0.93 \pm 0.30$ & $\begin{array}{l}1.56 \pm \\
0.76\end{array}$ & $\begin{array}{l}1.32 \pm \\
1.41\end{array}$ \\
\hline M3_2 & $0.01 \pm 0.02$ & $\begin{array}{l}0.03 \pm \\
0.03\end{array}$ & $0.02 \pm 0.03$ & $\begin{array}{l}0.34 \pm \\
0.37\end{array}$ & $\begin{array}{l}0.20 \pm \\
0.31\end{array}$ \\
\hline M4_1 & $1.12 \pm 1.34$ & $\begin{array}{l}0.41 \pm \\
0.39\end{array}$ & $0.26 \pm 0.13$ & $\begin{array}{l}1.03 \pm \\
1.01\end{array}$ & $\begin{array}{l}1.41 \pm \\
1.30\end{array}$ \\
\hline M4_2 & $0.02 \pm 0.03$ & $\begin{array}{l}0.21 \pm \\
0.21\end{array}$ & $0.07 \pm 0.04$ & $\begin{array}{l}0.35 \pm \\
0.12\end{array}$ & $\begin{array}{l}0.33 \pm \\
0.21\end{array}$ \\
\hline Overall & $0.72 \pm 1.52$ & $\begin{array}{l}1.12 \pm \\
2.47\end{array}$ & $\begin{array}{l}31.28 \pm \\
95.96\end{array}$ & $\begin{array}{l}19.05 \pm \\
58.14\end{array}$ & $\begin{array}{l}26.61 \pm \\
110.54\end{array}$ \\
\hline
\end{tabular}

Total abundance reflects the mean abundance (day and night) for the whole population (blastozooids and oozoids) at each station.

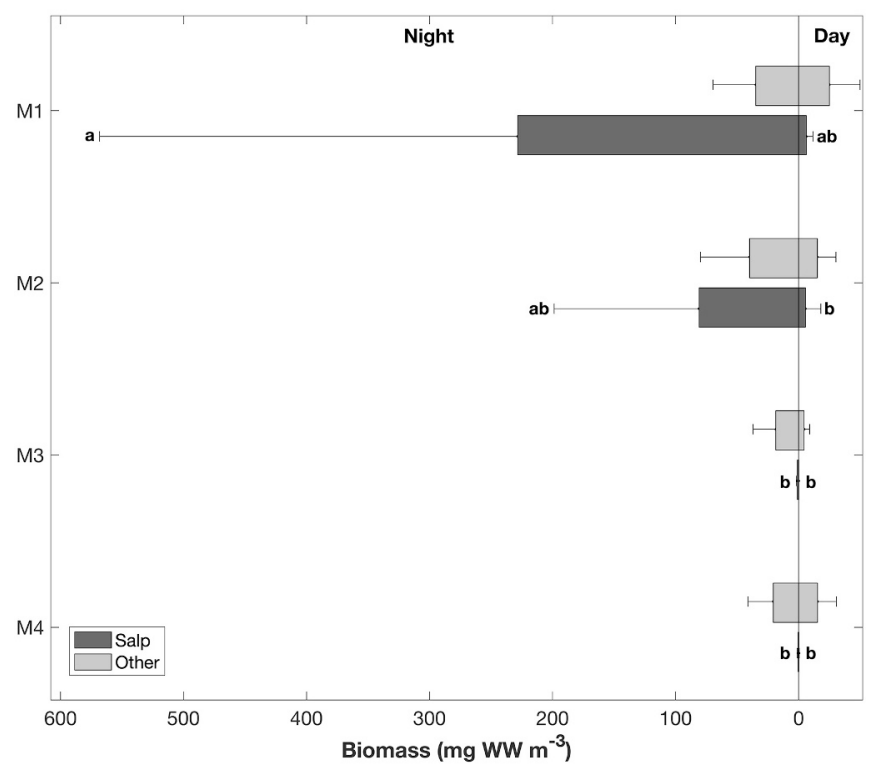

Fig. 4. Day and night mean biomass $( \pm \mathrm{SD})$ of $S$. thompsoni (salp) and other micronekton (other) sampled at stations M1 - M4. Letters (a, b) denote significant difference in $S$. thompsoni biomass at $p<0.05$. Other micronekton biomass did not differ significantly between stations or during time of day. Salp biomass at M3 and M4 are larger than zero (see Table 3).

Hunt et al., 2011). It is well documented that shifts in frontal positions may cause a dramatic change in the plankton community composition, as was observed around the Kerguelen Islands (Hunt et al., 2011) and in other regions of the Southern Ocean (e.g. Atkinson et al., 1978; Deibel, 1980; Graham et al., 2001). Despite high patchiness, S. thompsoni regularly make up a significant portion of the net zooplankton in the vicinity of the APF, the Kerguelen Plateau region and northern Prydz Bay Region (Pakhomov, 1993a, 1993b; Hosie, 1994; Pakhomov, 1995; Pakhomov and Hunt, 2017; Kelly et al., 2020).

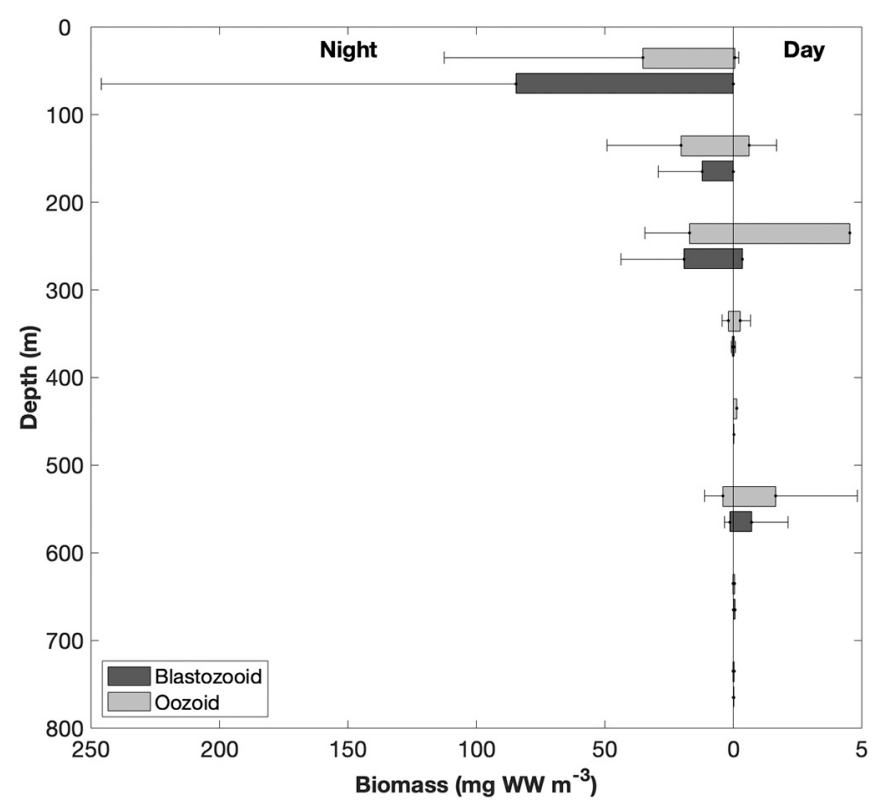

Fig. 5. Depth profile of mean blastozooid and oozoid biomass $( \pm S D)$ averaged across stations M1 - M4 for day and night. Day and night biomass are on displayed on different scales.

\subsection{Salpa thompsoni population dynamics}

Salpa thompsoni population dynamics is highly cyclical and seasonal (Foxton, 1966). While bud release (oozoid reproduction) generally occurs intermittently from spring to autumn, the oozoid release (blastozooid reproduction) is generally restricted to the late summer/autumn (Foxton, 1966; Henschke and Pakhomov, 2018). Consequently, summer blastozooid populations are usually right-skewed and dominated by smaller individuals, whereas by autumn, blastozooid sizes are more evenly distributed and dominated by males (Henschke and Pakhomov, 2018). There are observations of the oozoid reproduction during the Austral winter suggesting year around chain release activities (Pakhomov and Hunt, 2014). The blastozooid reproduction often begins in summer, peaking in autumn, where oozoid populations are characterized by recently released and young individuals (Henschke and Pakhomov, 2018).

During our study, there was ongoing oozoid reproduction at all locations, but variable blastozooid reproduction. Blastozooid reproduction was prominent at M1 and M2, confirmed by the presence of stage 0 oozoids, high proportions of males at M2, and overall higher salp abundances. Alternatively, at M3 and M4 blastozooids were less abundant, sexually immature (no reproductive stage 4 or males) and no newly released oozoids. Overall, M1 and M2 populations were more indicative of a typical autumn population, whereas M3 and M4 populations resembled characteristics of a summer population. It is possible that the early summer phytoplankton bloom as well as continued relatively high chlorophyll $a$ concentrations at M1 and M2 may have allowed the salp population to develop more rapidly. Comparably, at M3 and M4 the salp population development could been delayed (Henschke and Pakhomov, 2018). It is thus plausible that preceding environmental conditions played a major role in the development of $S$. thompsoni populations. At this point, it is hard to discount that advection processes could have also transported and mixed in salps from other locations, particularly at stations (i.e. M1) with the residence time $<10$ days.

\subsection{Salpa thompsoni growth rates}

S. thompsoni growth rates calculated in this study $\left(0.45-7.01 \% \mathrm{~d}^{-1}\right)$ fell within previously calculated growth rates near the Antarctic 

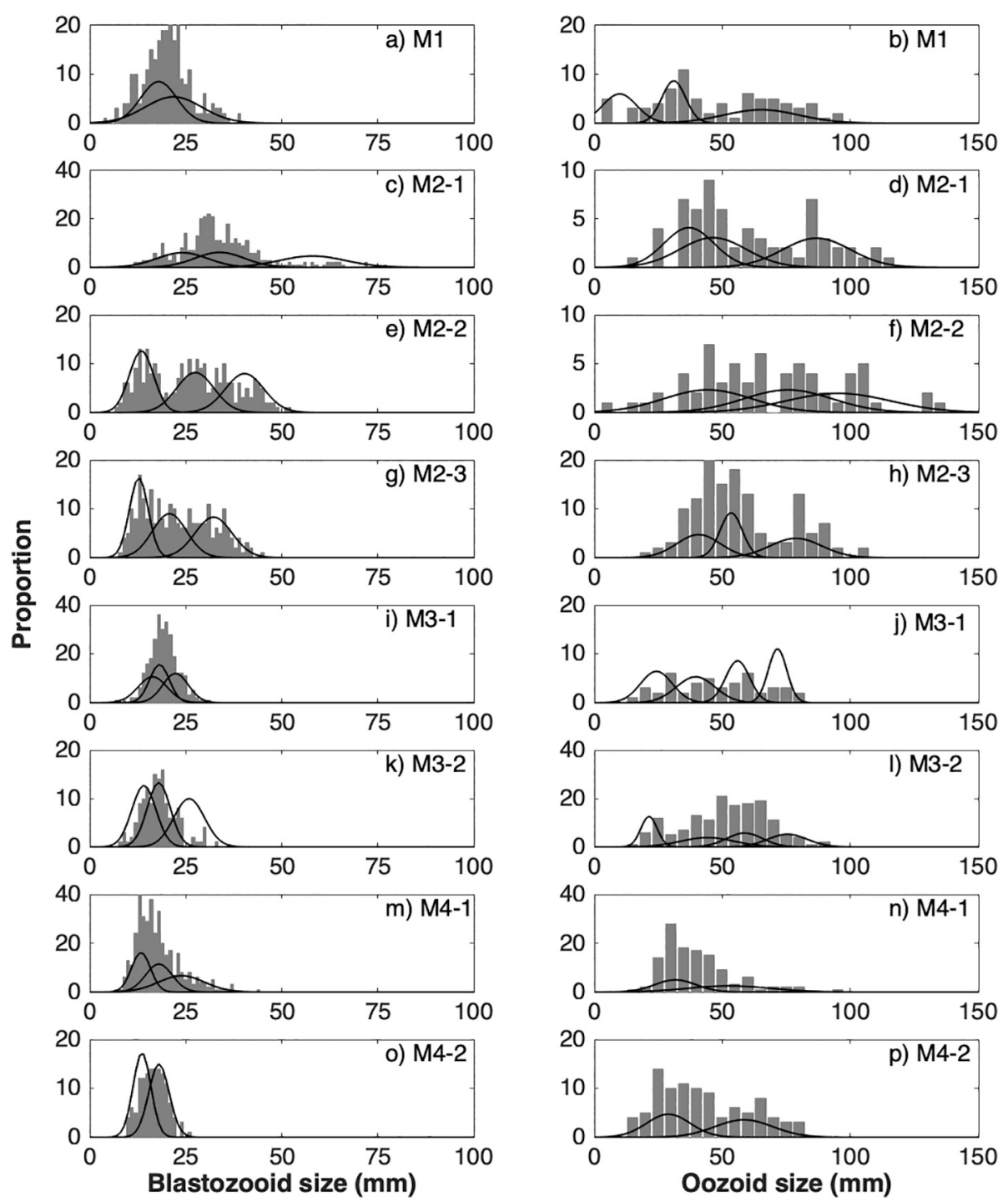

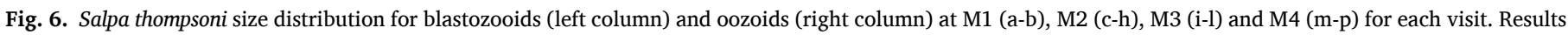
from cohort analysis are overlaid as black lines. Details of visits are given in Table 1.

Peninsula $0.3-4.6 \% \mathrm{~d}^{-1}$ (Loeb and Santora, 2012) and at the APF, 3.7-20.7\% $\mathrm{d}^{-1}$ (Pakhomov and Hunt, 2017). Both temperature and food availability are known to influence salp growth rates (Heron, 1972; Deibel, 1982; Heron and Benham, 1984), with the fastest calculated growth rates for $S$. thompsoni occurring in warm $\left(3-4{ }^{\circ} \mathrm{C}\right)$, chlorophyll $a$ rich APF water (Pakhomov and Hunt, 2017), and slower growth rates occurring in the cool $\left(-1-2{ }^{\circ} \mathrm{C}\right)$ Antarctic Peninsula waters (Loeb and Santora, 2012). Salpa thompsoni generally migrate to approximately 500 $\mathrm{m}$ depth (Nishikawa and Tsuda, 2001), and in this study migrated from $518 \mathrm{~m}$ in the day to $200 \mathrm{~m}$ at night. Generally, the Antarctic Polar Front, where the highest abundances of $S$. thompsoni are found (Henschke and Pakhomov, 2018), is defined by warm surface waters $\left(3-5^{\circ} \mathrm{C}\right)$, but a $2{ }^{\circ} \mathrm{C}$ minimum at 100-300 $\mathrm{m}$ deep (Botnikov, 1963). Therefore, like in this study, $S$. thompsoni populations at the APF are likely experiencing a temperature range of $2-5{ }^{\circ} \mathrm{C}$ as they migrate vertically. Despite similar environmental setting to the APF study, the chlorophyll $a$ concentrations during our investigation was over 6 fold lower $\left(0.3 \mathrm{mg} \mathrm{m}^{-3}\right)$ than in Pakhomov and Hunt (2017). A recent modelling study identified that due to the higher energetic cost of reproduction, oozoids require $40 \%$ more carbon compared to blastozooids to partition the same energy towards growth (Henschke et al., 2018). If oozoids in this study were not able to consume enough carbon because of lower chlorophyll $a$ concentrations, this could explain the reduced oozoid growth rates, despite optimum temperatures, at the time of sampling. This was mirrored by significantly larger oozoids sampled in areas with persistently higher food availability (M1 and M2).

\subsection{Salpa thompsoni in the Kerguelen Plateau ecosystem}

Modest abundances of $S$. thompsoni observed in this study are consistent with observations from other oceanographically similar areas of the Southern Ocean (e.g., the APF; Atkinson et al., 2017). This indicates that $S$. thompsoni swarms in productive areas of the Indian sector are at least as abundant as in more frequently sampled areas of the Southern Ocean (e.g. the Atlantic sector), highlighting the need to better understand their role in the Indian sector ecosystems (Foxton, 1966; Pakhomov et al., 2002). The unique oceanographic setting of the Kerguelen region, potentially increasing retention and deflection of warmer ACC waters southward (Lanin et al., 1987), is likely a precursor of large salp blooms developing over the plateau (Foxton, 1966; Pakhomov, 1993a, 2000). It was also observed that in the northern Prydz Bay Region years with stronger southward intrusions of warm waters are accompanied by high $S$. thompsoni densities (Pakhomov, 2000; Trebilco et al., 2019). As Antarctic krill in the Indian sector may be more sensitive 

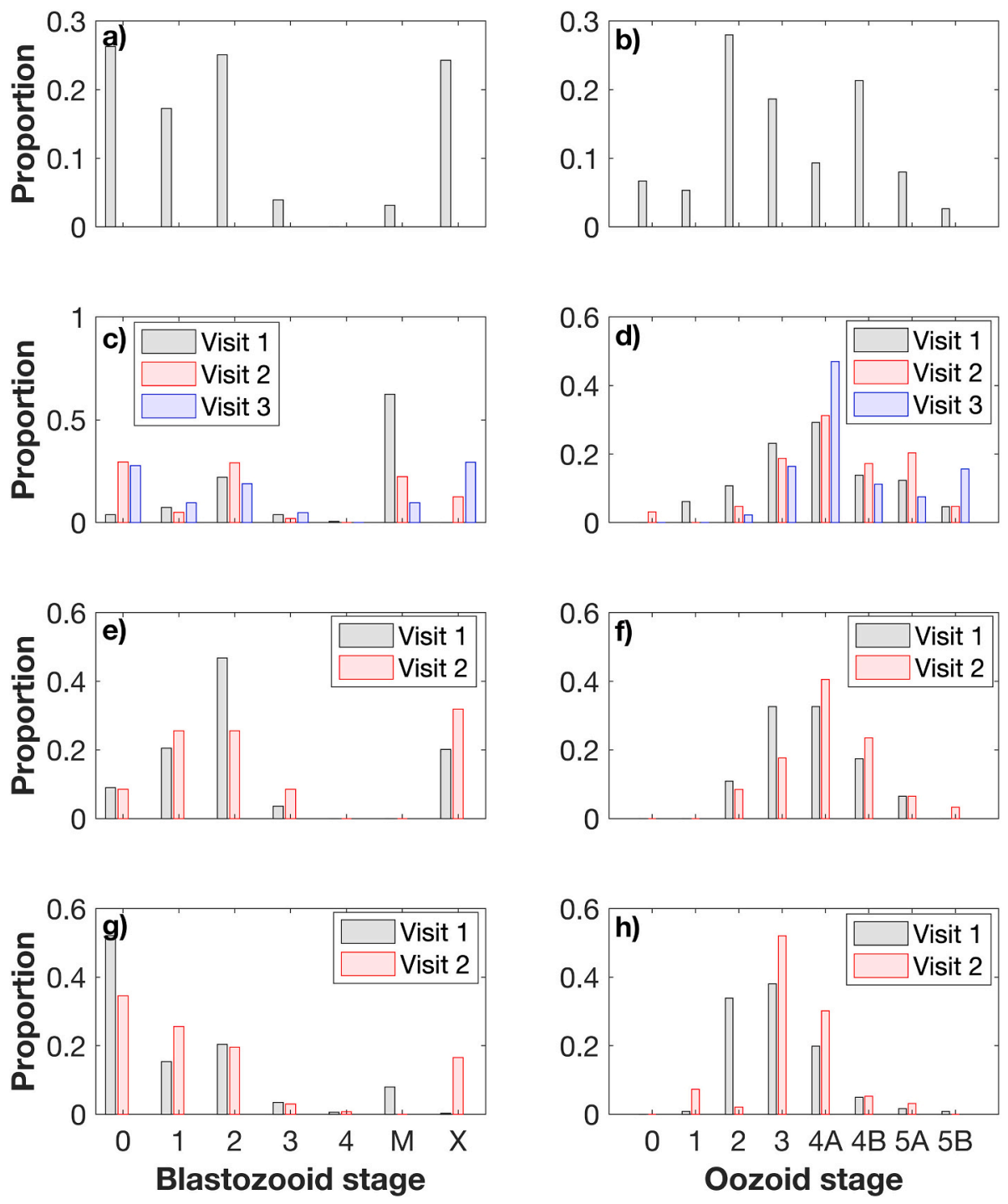

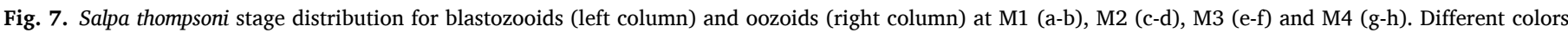
represent different visits to each station. Details of visits are given in Table 1 .

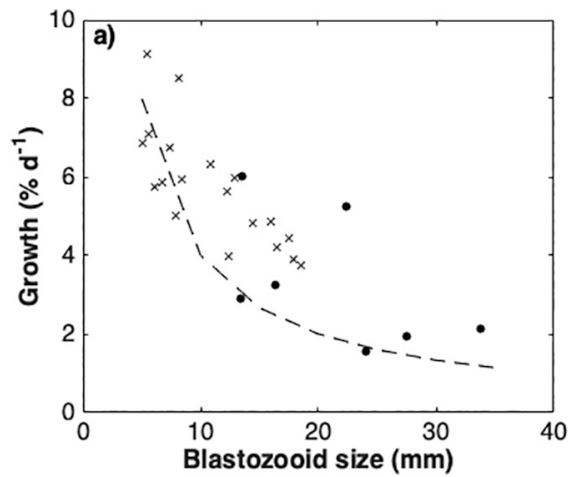

to the increased competition compared to Antarctic krill in the Atlantic sector (Murphy et al., 2017), the current study expands our understanding of the salp population dynamics in this area. This is particularly important in the light of future ecosystem re-structuring under projected climate change scenarios.

In our study, S. thompsoni dominated the micronekton biomass at M1

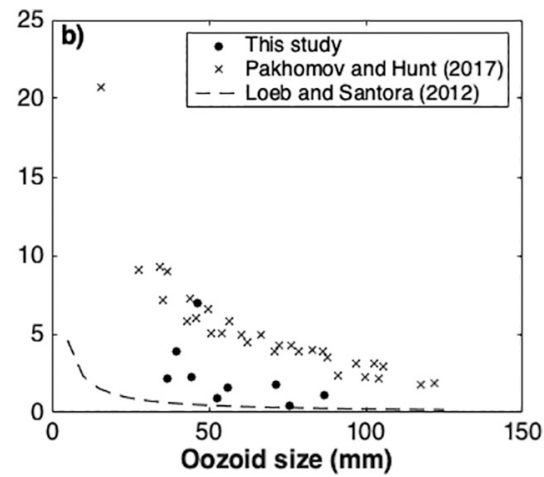

Fig. 8. Salpa thompsoni mean relative growth rates for a) blastozooids and b) oozoids calculated from repeated sampling at stations M2, M3 and M4 (circles). Overlaid are mean relative growth rates for $S$. thompsoni a) blastozooids and b) oozoids from repeated sampling in the Antarctic Polar Front (crosses; Pakhomov and Hunt, 2017) and Antarctic Peninsula (dashed line; Loeb and Santora, 2012). Values from Loeb and Santora (2012) are presented as growth curves as raw data were not available. 
respectively, significant density differences across stations are clearly driven by the variable nature of salp populations (Foxton, 1966). The Mesopelagos trawl used in our study targets organisms that are within the prey size range of vertebrate predators. Interestingly, while it would have undersampled the smaller grazing organisms (i.e. potential competitors of $S$. thompsoni), it highlights that $S$. thompsoni is an important part of the potential prey field of vertebrate predators. The Kerguelen Plateau region is a crucial feeding ground for significant midwater and demersal fish populations as well as numerous top predators including sea birds, seals and whales (Guinet et al., 1996; Cherel et al., 2005). Although the above mentioned apex predators mainly consume crustaceans and fish, recent genetic studies highlighted the dietary significance of gelatinous zooplankton, including salps for fish and penguins (e.g. Cavallo et al., 2018; Diaz Briz et al., 2018; Clarke et al., 2019). It is, therefore, particularly important to assess the impact that $S$. thompsoni may have on the local pelagic ecosystem as both a potential competitor or as a micronektonic prey.

\subsection{Concluding remarks}

These are the first estimates of $S$. thompsoni population dynamics and growth rates on the Kerguelen Plateau. S. thompsoni densities on the Kerguelen Plateau fell within previous estimates for populations in the APF, and were similar to limited studies in the area. The impact of $S$. thompsoni blooms on the local Kerguelen ecosystem may be prominent, particularly in late summer, through potential competition with smaller herbivorous zooplankton. While prior environmental conditions appeared to be an important factor in determining the success and development of $S$. thompsoni populations, salp growth rates are highly variable and likely indicative of current conditions. Salpa thompsoni abundance and population dynamics observed here were consistent with patterns observed in better-studied sectors of the Southern Ocean with similar environmental conditions. More studies on $S$. thompsoni across multiple seasons are needed to understand better their dynamics over the Kerguelen Plateau as well as their 'invasion' potential into the Prydz Bay and adjacent southern regions (Pakhomov, 2000).

\section{Declaration of Competing Interest}

None.

\section{Acknowledgements}

We thank B. Quéguiner, the PI of the MOBYDICK project, for providing us the opportunity to participate to this cruise, the chief scientist I. Obernosterer and the captain and crew of the R/V Marion Dufresne for their enthusiasm and support aboard during the MOBYDICK-THEMISTO cruise (doi:10.17600/18000403). This work was supported by the French oceanographic fleet ("Flotte océanographique française"), the French ANR ("Agence Nationale de la Recherche", AAPG 2017 program, MOBYDICK Project number: ANR-17-CE01-0013), and the French Research program of INSU-CNRS LEFE/CYBER ("Les enveloppes fluides et l'environnement" - "Cycles biogéochimiques, environnement et ressources"). This research was partially supported by the NSERC Discovery Grant RGPIN-2014-05107 held by EA Pakhomov.

\section{Appendix A. Supplementary data}

Supplementary data to this article can be found online at https://doi. org/10.1016/j.jmarsys.2020.103489.

\section{References}

Atkinson, L.P., Paffenhofer, G.A., Dunstan, W.M., 1978. The chemical and biological effect of a gulf stream intrusion off St. Augustine, Florida. Bull. Mar. Sci. 28, 667-679.
Atkinson, A., Hill, S.L., Pakhomov, E., Siegel, V., Anadon, R., Chiba, S., Daly, K.L., Downie, R., Fielding, S., Fretwell, P., Gerrish, L., Hosie, G.W., Jessop, M.J., Kawaguchi, S., Krafft, B.A., Loeb, V.J., Nishikawa, J., Peat, H.J., Reiss, C.S., Ross, R. M., Langdon, B., Quetin, L.B., Schmidt, K., Steinberg, D.K., Subramaniam, R.C., Tarling, G.A., Ward, P., 2017. KRILLBASE: a circumpolar database of Antarctic krill and salp numerical densities, 1926-2016. Earth Syst. Sci. Data 9, 193-2107.

Béhagle, N., Cotté, C., Lebourges-Dhaussy, A., Roudaut, G., Duhamel, G., Brehmer, P., Josse, E., Cherel, Y., 2017. Acoustic distribution of discriminated micronektonic organisms from a bi-frequency processing: the case study of eastern Kerguelen oceanic waters. Prog. Oceanogr. 156, 276-289.

Blain, S., Tréguer, P., Belviso, S., Bucciarelli, E., Denis, M., Desabre, S., Fiala, M., MartinJezequel, V., Le Fevre, J., Mayzaud, P., Marty, J.-C., Razouls, S., 2001. A biogeochemical study of the island mass effect in the context of the iron hypothesis: Kerguelen Islands, Southern Ocean. Deep-Sea Res. I Oceanogr. Res. Pap. 48, 163-187.

Blain, S., Quéguiner, B., Armand, L.K., Belviso, S., Bombled, B., Bopp, L., Bowie, A. Brunet, C., Brussard, C., Carlotti, F., Christaki, U., Corbiere, A., Durand, I., Ebersbach, F., Fuda, J.-L., Garcia, N., Gerringa, L., Griffiths, B., Guigue, C., Guillerm, C., Jacquet, S., Jeandel, C., Laan, P., Lefevre, D., Lomonaco, C., Malits, A., Mosseri, J., Obernosterer, I., Park, Y.-H., Picheral, M., Pondaven, P., Remeny, T., Sandroni, V., Sarthou, G., Savoye, N., Scouarnec, L., Souhaut, M., Thuiller, D., Timmermans, K., Trull, T.W., Uitz, J., Van-Beek, P., Veldhuis, M., Vincent, D., Viollier, E., Vong, L., Wagener, T., 2007. Impacts of natural iron fertilisation on the Southern Ocean. Nature 446, 1070-1074.

Bocher, P., Cherel, Y., Labat, J.P., Mayzaud, P., Razouls, S., Jouventin, P., 2001. Amphipod-based food web: Themisto gaudichaudii caught in nets and by seabirds in Kerguelen waters, southern Indian Ocean. Mar. Ecol. Prog. Ser. 223, 261-276.

Botnikov, V.N., 1963. Geographic position of the Antarctic convergence zone in the Southern Ocean (English translation). Sov. Antarct. Exped. Inf. Bull. 4, 324-327.

Carlotti, F., Thibault-Botha, D., Nowaczyk, A., Lefevre, D., 2008. Zooplankton community structure, biomass and role in carbon fluxes during the second half of a phytoplankton bloom in the eastern sector of the Kerguelen shelf (January February 2005). Deep-Sea Res. II Top. Stud. Oceanogr. 55, 720-733.

Cavallo, C., Chiaradia, A., Deagle, B.E., McInnes, J.C., Sanchez, S., Hays, G.C., Reina, R. D., 2018. Molecular analysis of predator scats reveals role of salps in temperate inshore food webs. Front. Mar. Sci. 5, 1-14.

Cherel, Y., Bost, C.-A., Guinet, C., Weimerskirch, H., 2005. Feeding habits of seabirds and marine mammals of the Kerguelen Archipelago. In: Palomares, M.L.D.E.A. (Ed.), Modeling Antarctic Marine Ecosystems. Fisheries Center Research Reports, pp. 31-36.

Clarke, L.J., Trebilco, R., Walters, A., Polanowski, A.M., Deagle, B.E., 2019. What can DNA in fish stomachs tell us about the Southern Ocean? In: Welsford, D., Dell, J., Duhamel, G. (Eds.), The Kerguelen Plateau: Marine Ecosystem and Fisheries. Proceedings of the Second Symposium. Australian Antarctic Divison, Kingston, Tasmania, Australia.

Condie, S.A., Dunn, J.R., 2006. Seasonal characteristics of the surface mixed layer in the Australasian region: implications for primary production regimes and biogeography. Mar. Freshw. Res. 57, 569-590.

Cotté, C., d'Ovidio, F., Dragon, A.C., Guinet, C., Lévy, M., 2015. Flexible preference of southern elephant seals for distinct mesocale features within the Antarctic circumpolar current. Prog. Oceanogr. 131, 46-58.

Deibel, D., 1980. Feeding, Growth and Swarm Dynamics of Neritic Tunicates from the Georgia Bight. University of Georgia, Athens.

Deibel, D., 1982. Laboratory determined mortality, fecundity and growth-rates of Thalia democratica Forskal and Dolioletta gegenbauri Uljanin (Tunicata, Thaliacea). J. Plankton Res. 4, 143-153.

Diaz Briz, L., Sanchez, F., Mari, N., Genzano, G., 2018. Seasonal variation of gelatinous plankton consumption by fish in the South-Western Atlantic Ocean: a question of strategy. Mar. Biol. Res. 14, 739-751.

d'Ovidio, F., Della Penna, A., Trull, T.W., Nencioli, F., Pujol, M.I., Rio, M.H., Park, Y.-H., Cotté, C., Zhou, M., Blain, S., 2015. The biogeochemical structuring role of horizontal stiring: Lagrangian perspectives on iron delivery downstream of the Kerguelen plateau. Biogeosciences 12, 5567-5581.

Dubischar, C.D., Bathmann, U.V., 1997. Grazing impact of copepods and salps on phytoplankton in the Atlantic sector of the Southern Ocean. Deep-Sea Res. Part II 44, 415-433.

Duhamel, G., Koubbi, P., Ravier, C., 2000. Day and night mesopelagic fish assemblages off the Kerguelen Islands (Southern Ocean). Polar Biol. 23, 106-112.

Everson, I., 2000. Krill: Biology, Ecology and Fisheries. Blackwell Science, London.

Foxton, P., 1966. The distribution and life-history of Salpa thompsoni Foxton with observations on a related species, Salpa gerlachei Foxton. Discov. Rep. 34, 1-116.

Graham, W.M., Pagès, F., Hamner, W.M., 2001. A physical context for gelatinous zooplankton aggregations: a review. Hydrobiologia 451, 199-212.

Guinet, C., Cherel, Y., Ridoux, V., Jouventin, P., 1996. Consumption of marine resources by seabirds and seals in Crozet and Kerguelen waters: changes in relation to consumer biomass 1962-85. Antarct. Sci. 8, 23-30.

Henschke, N., Pakhomov, E.A., 2018. Latitudinal variations in Salpa thompsoni reproductive fitness. Limnol. Oceanogr. 64, 575-584.

Henschke, N., Everett, J.D., Richardson, A.J., Suthers, I.M., 2016. Rethinking the role of salps in the ocean. Trends Ecol. Evol. 31, 720-733.

Henschke, N., Pakhomov, E.A., Groeneveld, J., Meyer, B., 2018. Modelling the life cycle of Salpa thompsoni. Ecol. Model. 387, 17-26.

Heron, A.C., 1972. Population ecology of a colonizing species - pelagic tunicate Thalia democratica. 1. Individual growth-rate and generation time. Oecologia 10, 269-293.

Heron, A.C., Benham, E.E., 1984. Individual growth rates of salps in three populations. J. Plankton Res. 6, 811-828. 
Hoover, C., Pitcher, T.J., Pakhomov, E.A., 2012. The Antarctic peninsula marine ecosystem model and simulations 1978-present. Fish. Center Res. Rep. 20, 108-188.

Hosie, G.W., 1994. The macrozooplankton communities in the Prydz Bay region, Antarctica. In: Southern Ocean Ecology: the BIO-MASS Perspective (S.Z., E.-S., ed), pp. 99-123.

Hunt, B.P.V., Pakhomov, E.A., Williams, R., 2011. Comparative analysis of the 1980s and 2004 macrozooplankton composition and distribution in the vicinity of Kerguelen and heard islands: seasonal cycles and oceaographic forcing of long-term change. In: Duhamel, G., Welsford, D. (Eds.), The Kerguelen Plateau: Marine Ecosystems and Fisheries, pp. 79-92.

Kelly, P., Corney, S.P., Melbourne-Thomas, J., Kawaguchi, S., Bestley, S., Fraser, A., Swadling, K.M., 2020. Salpa thompsoni in the Indian sector of the Southern Ocean: environmental drivers and life history parameters. Deep-Sea Res. II Top. Stud. Oceanogr. 174, 104789.

Lanin, V.I., Aseev, Y.P., Klyausov, A.V., 1987. Oceanographic prerequisites of formation and interannual variability in the condition of the high productive ecosystem of the Cooperation Sea. In: Novikov, NP, Alekseev, AP (Eds.), Resources of the Antarctic zone of the ocean and problems of their rational utilization. YugNIRO Publishers, Kerch, pp. 34-36.

Le Quéré, C., Buitenhuis, E.T., Moriarty, R., Alvain, S., Aumont, O., Bopp, L., Chollet, S. Enright, C., Franklin, D.J., Geider, R.J., Harrison, S.P., Hirst, A.G., Larsen, S., Legendre, L., Platt, T., Prentice, I.C., Rivkin, R.B., Sailley, S., Sathyendranath, S., Stephens, N., Vogt, M., Vallina, S.M., 2016. Role of zooplankton dynamics for Southern Ocean phytoplankton biomass and global biogeochemical cycles. Biogeosciences 13, 4111-4133.

Loeb, V.J., Santora, J.A., 2012. Populaton dynamics of Salpa thompsoni near the Antarctic peninsula: growth rates and interannual variations in reproductive activity (1993 2009). Prog. Oceanogr. 96, 93-107.

Maldonado, M.T., Surma, S., Pakhomov, E.A., 2016. Southern Ocean biological iron cycling in the pre-whaling and present ecosystems. Philos. Trans. R. Soc. Lond. Ser. A 374, 20150292 .

Meillat, M., 2012. Essais du chalut mesopelagos pour le programme MYCTO 3D-MAP de l'IRD, a bord du Marion Dufresne (du 10 au 21 aout 2012).

Murphy, E.J., Thorpe, S.E., Tarling, G.A., Watkins, J.L., Fielding, S., Underwood, P., 2017. Restricted regions of enhanced growth of Antarctic krill in the circumpolar Southern Ocean. Sci. Rep. 7, 1-14.

Nishikawa, J., Tsuda, A., 2001. Diel vertical migration of the tunicate Salpa thompsoni in the Southern Ocean during summer. Polar Biol. 24, 299-302.

Olivar, M.P., Hulley, P.A., Castellón, A., Emelianov, M., López, C., Tuset, V.M., Contreras, T., Molí, B., 2017. Mesopelagic fishes across the tropical and equatorial Atlantic: biogeographical and vertical patterns. Prog. Oceanogr. 151, 116-137.

Pakhomov, E.A., 1989. Macroplankton Distribution in the Central Part of the Indian Sector of Antarctica During Summer of 1984-1986, 28. The Antarctic, Nauka Press, Moscow, pp. 145-158.

Pakhomov, E.A., 1993a. Faunistic Complexes of Macroplankton in the Cooperation Sea (Antarctica), 32. The Antarctic, Nauka Press, Moscow, pp. 94-110.
Pakhomov, E.A., 1993b. Macroplankton of waters contiguous to the Kerguelen archipelago. In: Duhamel, G. (Ed.), Les Rapports des a la Mer: Campagnes SKALP 1987 et 1988 Aux Iles Kerguelen a Bord des Navires "SKIF" et "KALPER". l'Institut Francais pour la Recherche et la Technologie Polaries (IFRTP) Publishers, Paris, pp. 104-112.

Pakhomov, E.A., 1995. Composition and distribution of macrozooplankton around the Antarctic islands of Kerguelen. Hydrobiol. J. (Kiev) 31, 21-32.

Pakhomov, E.A., 2000. Demography and life cycle of Antarctic krill, Euphausia superba, in the Indian sector of the Southern Ocean: long-term comparison between coastal and open-ocean regions. Can. J. Fish. Aquat. Sci. 57, 68-90.

Pakhomov, E.A., Hunt, B.P.V., 2014. Macrozooplankton and micronekton dynamics during the Antarctic winter. In: Reports on Polar and Marine Research (Berichte zur Polar- und Meeresforschung), 674, pp. 31-36.

Pakhomov, E.A., Hunt, B.P.V., 2017. Trans-Atlantic variability in ecology of the pelagic tunicate Salpa thompsoni near the Antarctic polar front. Deep-Sea Res. II Top. Stud. Oceanogr. 138, 126-140.

Pakhomov, E.A., Froneman, P.W., Perissinotto, R., 2002. Salp/krill interactions in the Southern Ocean: spatial segregation and implications for the carbon flux. Deep-Sea Res. II Top. Stud. Oceanogr. 49, 1881-1907.

Park, Y.-H., Roquet, F., Durand, I., Fuda, J.-L., 2008. Large-scale circulation over and around the northern Kerguelen plateau. Deep-Sea Res. II Top. Stud. Oceanogr. 55, 566-581.

Schlitzer, R., 2002. Carbon export fluxes in the Southern Ocean: results from inverse modelling and comparison with satellite based estimates. Deep-Sea Res. II Top. Stud. Oceanogr. 49, 1623-1644.

Suprenand, P.M., Ainsworth, C.H., 2017. Trophodynamic effects of climate changeinduced alterations to primary productions along the western Antarctic peninsula. Mar. Ecol. Prog. Ser. 569, 37-54.

Trebilco, R., Walters, A., Melbourne-Thomas, J., Bestley, S., Cox, M., Gastauer, S., Constable, A., 2019. Mesopelagic community structure on the southern Kerguelen Axis. In: Welsford, D., Dell, J., Duhamel, G. (Eds.), The Kerguelen Plateau: marine ecosystem and fisheries. Proceedings of the Second Symposium. Australian Antarctic Division, Kingston, Tasmania, Australia, pp. 49-54.

Trull, T.W., Davies, D.M., Dehairs, F., Cavagna, A.-J., Lasbleiz, M., Laurenceau-Cornec, E. C., d'Ovidio, F., Planchon, F., Leblanc, K., Quéguiner, B., Blain, S., 2015. Chemometric perspectives on plankton community responses to natural iron fertilisation over and downstream of the Kerguelen plateau in the Southern Ocean. Biogeosciences 12, 1029-1056.

Uitz, J., Claustre, H., Griffiths, F.B., Ras, J., Garcia, N., Sandroni, V., 2008. A phytoplankton class-specific primary production model applied to the Kerguelen Islands region (Southern Ocean). Deep-Sea Res. I Oceanogr. Res. Pap. 56, 541-560.

Voronina, N.M., 1998. Comparative abundance and distribution of major filter-feeders in the Antarctic pelagic zone. J. Mar. Syst. 17, 375-390.

Williams, A., Koslow, J.A., 1997. Species composition, biomass and vertical distribution of micronekton over the mid-slope region off southern Tasmania, Australia. Mar. Biol. 130, 259-276. 